\title{
Structuralism as an Approach to the Theoretical Construction of Poetic Narratology
}

\author{
Jun Luo ${ }^{1}$, Gui-jun $\mathrm{Li}^{2}$ \\ ${ }^{1}$ School of Foreign Languages, Zhaotong University, Zhaotong, China. \\ ${ }^{2}$ School of Foreign Languages, Dianxi Normal University of Science and Technology, Lincang, China
}

\begin{abstract}
Many scholars international academic circle have applied narratological theories into novel studies, drama studies, film studies, cultural studies, educational studies, as well as narrative space studies in order to establish novelist narratogogy, dramatic narratology, filmic narratology, cultural narratology, educational narratology, and spatial narratology respectively. Few of them have failed to apply narrative theories into poetic studies, fewer of them into the studies of poetic narratology and none of them into the studies of poetic narratology from the perspective of structuralism. Hence, this essay aims to make a study of its theoretical foundation based on structuralism.
\end{abstract}

Keywords-Poetic Narratology, Approach, Structuralism, Theoretical Construction

\section{AN INTRODUCTION TO THE THEORETICAL CONSTRUCTION OF POETIC NARRATOLOGY}

\subsection{The Research Aims}

In general, it ought to be elaborated in the following four folds that the research aim of this study is to seek for an evident approach to the theoretical foundation of poetic narratology from the perspective of structuralism based on the academic motivation of questing for the specific solutions to the problems in the construction of poetic narratology.

Firstly, this study aims to construct and develop a new theory that can be used to find out one of the theoretical paradigms of poetic narratology that ought to be based on the poetic narration in poetic narrative texts from the perspective of structuralism by making a structuralist analysis or giving a structuralist interpretation of the structural specificity in the narration of poetic narrative texts where this essay has been expected to make an exploration of how to construct poetic narratology grounded on the illumination gained from the reading practice of the theories of structuralist narratology. In a sense, this can be counted as the first exploration of constructing, developing and developing the entire theoretical framework of poetic narratology.
Secondly, this study is aimed to shed some lights on poetic readers, poetic scholars, poetic critics and poetic theorists in their reading practices, their researching practices, their analyzing practices, criticizing practices as well as their theorizing practices while they are reading, researching, analyzing, criticizing and theorizing a variety of poetic narrative texts after the narrative poets have taken pains to finish the textual construction of their poetic narrative texts either for delight or for ornament in spite of the textual interference of the poetic narrative texts produced by their poetic forebears.

Thirdly, this study aims to continue and promote the narrative studies of constructing a narrative theories of poetic narrative texts just as what has been proposed in America by a distinguished professor of English at the Ohio State University and one of the founders of Project Narrative at this university named Brian McHale in one of his essays titled Beginning to Think about Narrative in Poetry published on the globally famous narrative journal in the field of narrative studies called Narrative in 2009. Fourthly, this study aims to continue the innovative spirits of academic originality and academic values just as what has been exemplified by those Chinese academic forebears including Fei Jiang and Shang Bi-wu who have set a good example for Chinese scholars in terms of developing academic innovation and have been keeping in their minds that they ought to achieve an original development as well as irreplaceable betterment in the theoretical studies of poetic narratology from different perspectives instead of following what has been proposed by other foreign scholars.

\subsection{The Research Backgrounds}

In accordance with the specific research aim of this study, the research background of this study needs to be mainly explicated in four folds.

In the first place, with the shift of narratologists' attentions from classic narratology to post-classic narratology, the thoughts of combining narrative studies with structuralism have been made much more difficult to draw their attentions, let alone raise their academic interest, for they have, to some extent, been reluctant to 
pay enough attention to those studies because the shifts of their academic attentions have been running short of their academic passions to do so. Therefore, it is in this case that the studies of constructing the theoretical frameworks of poetic narratology by means of directing at combining narrative studies with poetic studies are unlikely to be favored by most narratologist who are in favor of popularizing the studies in the narrative turns from classic narratology to post-classic narratology. In order to catch pace with the academic fashion of this narrative turns, most of them have chosen to turn a blind eye to the studies of poetic narratology that has been blocked by the incredible academic unpopularity and indifference. In this academic context, most of them are unwilling to spare their academic time to rethink what narrative studies owe to poetic studies and vice versa.

In the second place, the narrative studies that have been made at present have little to do with poetic studies because most narratologists' interest lies not in the poetic narration of poetic narrative texts but in the novelist narration of classic novelist narrative texts. The harm those academic preferences will do to poetic narratology is for one thing that the narratologists who are good at novelist narration are not necessarily interested in poetic studies and for another thing the poetic critics who are good at poetic criticism are also not necessarily interested in narrative studies. In other words, it is difficult for them to do well in poetic studies and narrative studies at the same time.

However, the construction of poetic narratology is in bad need of those scholars who can make a study of poetic narratology ought to take interest in both poetic studies and narrative studies. After all, the novelist narration in novelist narrative texts is not identical with the poetic narration of poetic narrative texts even if they are likely to bear structural similarities to each other in more than one fold due to the specificity of the latter. Based on this narrative awareness, what is likely to be seen is that it is wrong to replace poetic narration with novelist narration and to neglect poetic narration owing to the strong influence of novelist narration on most narratologists. In this sense, this is one of the important academic contexts to carry out this study.

In the third place, Chinese literary educations for English majors offered in higher educational institutions have been focusing on a general introduction to the literary history that has been reduced to English and American literary history, the literary texts that have been limited in the selected English and American literary texts in the form of adaptations or excerpts of firstly novels, secondarily essays, thirdly plays and finally poetry, the literary criticism that has been produced by most critics who have been paying their attentions firstly to novels, secondarily to essays, thirdly to plays and finally to www.ijels.com poetry, as much as the literary theories including both Chinese literary theories and contemporary western literary theories that most Chinese undergraduate English majors have hardly been able to have opportunities to learn it let alone give an account of narrative studies in terms of narrative theory and narrative practice even though they have frequently been required or forced to finish their bachelor theses.

To some extent, the insufficiency of this literary education has great limitations on developing the literary ability, training the literary thinking, highlighting their literary literacy, strengthening the literary originality and broadening the horizons of undergraduate English majors who have been believed to be remarkably distinguishable from average English learners in many a fold.

In the fourth place, the interdisciplinary and trans-genre integration of narrative studies with other disciplinary studies, together with the narrative transition from classic narratology to post-classic narratology have made it a reality that a lot of new narrative theories have cropped up one after another. To name but a few, those narrative theories have included novelistic, essayistic, dramatic, cultural, filmic, musical, ethnic, religious, psychological, educational, medical, cognitive, commercial, journalist, spatial, media, advertisement, natural as well as unnatural narratology except for poetic narratology. In other words, no formal mention has been made of poetic narratology let alone the logical justification of it neither in poetic studies nor in narrative studies. This seems to be very unintelligible, for it is surprisingly unmatchable with the dominant and indomitable tune of the interdisciplinary qualities of the narrative studies that have been attaching a great importance to the academic turns of narrative studies.

In the fifth place, at present, the dominant position of narratology has already made it an academic fashion in literary studies all over the world but the poetic narration in poetic narrative texts for the theoretical foundation of poetic narratology has rarely been mentioned, discussed and explored as what has been done in novelist narration of novels, essayistic narration in essays and the dramatic narration in dramas. Therefore, it is the inexcusable duty for the poetic scholars, poetic critics and poetic theorists to popularize the poetic narration of poetic narrative texts and translate the academic identity of poetic scholars, poetic critics and poetic theorists into that of poetic narratologists while quickening the construction of poetic narratology.

\subsection{The Research Hypotheses}

To justify the narrative proposition elaborated above in the form of research aims in this essay, it is necessary to make it the major research hypothesis of this study that structuralism can be taken as one of the approaches to the

Page | 66 
theoretical foundation of poetic narratoloy as explicated following two minor research hypotheses.

As for the first minor research hypothesis of this study, it ought to be assumed in this study that the linguistic and narrative structures in the narrative language of poetic narrative texts are sharply different from those in other narrative texts like novels, essays and plays in terms of the special narrative structure of the narrative discourse, the narrative language, narrative space, narrative plot, narrative grammar and narrative time. That is because the poetic narrativity exemplfied in the implicit commonality and particularity of the narrative languages and actions of poetic narrative texts is likely to defamiliarize the explicit qualities of other narrative texts including essayist narrative texts, novelist narrative texts, dramatic narrative texts, filmic narrative texts, musical narrative texts, educational narrative texts, cognitive narrative texts, psychological narrative texts, medical narrative texts, commercial narrative texts, ethic narrative texts, religious narrative texts as well as journalist narrative texts.

As for the second minor research hypothesis of this study, it also ought to be assumed in this study that the transformation of the linguistic and narrative structure in the narrative language of poetic narrative texts has much to do with the expression and manifestation of the implications of those texts due to the differences of structural distribution and juxtaposition in linguistic and narrative sense from those of the narrative language in other narrative texts in a remarkable fashion, for the structural certainty and uncertainty of the language and narration in poetic narrative texts have much to do with the implicational certainty and uncertainty including the lexical certainty or uncertainty, syntactical certainty or uncertainty, semantic certainty or uncertainty as much as the pragmatic certainty or uncertainty in terms of the metamorphic qualities in the respects mentioned here.

For the sake of the sufficient justification of the major research hypothesis and those two minor research hypotheses of this study as proposed above in an evident way, a lot of explorations and analyses of the special linguistic and narrative structure as well as a bank of comparisons of the both the linguistic and narrative structure between poetic narrative texts and other narrative texts ought to be made of to make a distinction of poetic narrative texts from other narrative texts in more than one fold in terms of the difference of narrative theories and literary genres.

\subsection{The Research Significances 1.4.1 The Theoretical Significance}

The theoretical significances of this study will be likely to be embodied in the following four folds respectively including the significance of the theoretical exploration of www.ijels.com this study, the significance of theoretical breakthrough of this study, the significance of theoretical construction of this study, as well as the significance of theoretical innovation of this study in the sustainable and successive explorations of the theoretical constructions of poetic narratology based on a series of conspicuous analyses of the relevant linguistic and narrative structures exemplified in the narrative language in poetic narrative texts as dealt with below one after another.

The first significance of the theoretical significances of this study is the theoretical exploration of this study that is manifested in its theoretical quest for a poetic theory called poetic narratology and applied in the critical practices of poetic narrative texts to highlight the poetic narrativity of those texts, to broaden the understanding of poetic narration and widen the academic field of both poetic studies and narrative studies from the perspective of structuralism to reach the aims of disciplinarizing, theorizing, systematizing, logicalizing and scientizing the narrative mechanism of the relevant linguistic and narrative structures of the narrative language in the poetic narration in poetic narrative texts.

The second significance of the theoretical significances of this study is the theoretical breakthrough of this study that lies in the extension and promotion of both poetic studies and narrative studies in an interdisciplinary way to attach a greater emphasis on the narrativization in poetic texts and the poeticization of narrative theories by making a specific study of the specific structure of both the narrative language as well as the narrative plot of poetic narrative texts in order to reflect, to rethink or re-examine a mutual and interactive relationship between poetic studies and narrative studies.

The third significance of the theoretical significances of this study refers to the theoretical construction of this study that can be seen from the enrichment, development, betterment and construction of the theoretical framework of poetic narratology used to make a distinction from other narratologies in a systematic, logic and organic way like novelist narratology, dramatic narratology, essayist narratology etc., by the virtue of finding sufficient theoretical evidences from the possible illumination of structuralist linguistics and narratology at the transition of narrative studies from classic narratology to post-classic narratology.

The fourth significance of the theoretical significances of this study is manifested in the theoretical innovation of this study that has been typified in its academic optimality to take the first step toward the enlargement of narrative studies in poetic narrative texts in an interdisciplinary fashion and the expansion of poetic studies into narrative studies in a reciprocal way so as to seek for much greater progress in the theoretical studies of those two fields and 
lay a sound foundation for the future studies of poetic narratology.

\subsubsection{The Practical Significances}

The practical significances of this study explained in the following four respects one after another ought to be composed of the significance in the reading practices of poetic narrative texts, the significance in the criticizing practices of poetic narrative texts, the significance in the writing practices of poetic narrative texts and the significance in the teaching practices of poetic narrative texts.

The first practical significance of the practical significances of this study is related to the significance for the enrichment of the reading practices of the readers of poetic narrative texts in the process of the construction of poetic narratology as it is possible to help them to have a good understanding of the relationship between the transformation of the syntactical structure and its influence of the structure of the narrative language in poetic texts rather than making them deviating from each other from, distracting from each other and estranging from each other in their structuralist understanding of those texts from the perspective of structuralism. Moreover, their good knowledge of the all the structural constituents in the narration of poetic narrative texts under the guidance of the theoretical foregrounding and back grounding of poetic narratology is likely to help them avoid their possible misunderstanding misreading and misinterpreting those poetic narrative texts.

The second significance of the practical significances of this study lies in the criticizing practices of the poetic critics of the poetic narrative texts that is based on the illumination of poetic critics whose criticism is conducive for both the theoretical construction and the application of poetic narratology that can be seen in the process of guiding their everyday practices of poetic criticism for the aim of giving new interpretations of poetic narrative texts from new perspectives that can be found in the theoretical lights thrown by poetic narratology.

The third significance of the practical significances of this study is concerned with in the writing practices of narrative poets in their textual production of poetic narrative texts, for the suggestions they have given their readers in an implicit way is likely to be helpful for the present and future poets who will be likely to take those suggestions from their textual production of those poetic narrative texts so as to avoid the writing limitations of previous poets' writing experience and produce a lot of better poetic narrative texts as far as the narrative originality of poetic narrative texts are concerned.

The fourth significance of the practical significances of this study has much to do with the teaching practices of poetic teachers in their teaching process of the poetic www.ijels.com narrative texts, for they are likely to acquire possible interpretative experiences from their frequent references to this study in order to give a better illumination to their students and enrich their teaching experiences through their narrative reflection and interpretation of the poetic narrative texts they need to teach their students.

\section{A SURVEY OF THE DEVELOPMENT OF POETIC NARRATOLOGY}

Before taking into consider the theoretical construction of poetic narratology, it is crucial to take a good look at the term narratology and its origin whose theoretical lineage can be traced to Aristotle's Poetics even if modern narratology has been agreed by the Russian formalists, particularly Vladimir Propp to have begun with Russian formalism, is a theory of the structures of narrative that aims to investigate a structure, or to present a structural description, and the narratologist dissects the narrative phenomena into their component parts and then attempts to determine functions and relationships. However, in a modern sense, it derives from France, sweeps over other countries and becomes a trend of international studies regarding literary theory. Despite the birth of narratology in France, the word narratology is an anglicised French word narratologie firstly proposed in Russia by Tzvetan. Todorov.

The uprising of French narratology is closely related to a train of thought termed structuralism and firstly appeared in the middle $20^{\text {th }}$ century. Unlike the formation of traditional novelist theories, structuralism focuses on the movement of their attention from the internal studies of the text to external ones, laying weight on the intrinsic laws of the structure of literary texts and the relation between one of its elements and another. On account of the rapid development of structuralist narratology, studies in terms of the story structure and narrative techniques gained its important position in the development of the theories of novel criticism in 1960s.

It can be obviously seen that early narratology has been primarily applied to novelist studies and the studies of literary theory and literary criticism rather than those of the poetic narration of poetic narrative texts. It might be concluded that earlier application of narratology mostly centers on the temporalization of novelist texts that has been marked with the dominant studies of novels in the tradition of narratological studies and in the tradition of novelist studies. For this sake, the poetic theorists and interpreters can not but approached the poetic narration of poetic narrative texts from various perspectives like feminism, marxism, historicism, ecological criticism, new historicism, post-colonialism, formalism as well as new criticism in terms of the external studies of the poetic narration of poetic narrative texts. 
Among those perspectives mentioned above one after another respectively, new criticism has always been besting the perspectives related to other theories because poetic scholars or poetic critics who have been interested in the internal studies of poetic texts have been insisting that poetic texts should be interpreted in details from the perspective of new criticism because of the inerasable influence of such an academic values that the poetic studies based on poetic texts ought to be emphasized on the formal studies rather than thematic studies of poetic texts. For this sake, poetic studies have been reduced just to ontological studies from the perspective of new criticism on the ground that poetry scholars have rarely paid any attention to its content, its context as well as its consensus between readers and poets at all, but to its coherence, rhythms, metaphors, features as such. To put it simply, previous poetic studies are no more than the ontological studies of poetic texts owing to the failure of a variety of poetic scholars and poetic critics to combine poetic studies with narratology in the abstract sense.

In this case, poetic studies have been thrown into the corner of new critical studies that have been so popular with poetic scholars, poetic critics and poetic theorists that the theoretical insights of other literary theories have been thoroughly ruled out or at least overlooked. It is not until the latest moment that poetic studies have gradually liberated from the bonds and chains of its previous new critical studies to embrace other theories that can be adopted to interpret poetic texts.

In consistence with the paces to be kept with the proposition of a train of this academic thought, it has been considered to be appropriate to put narratology into the practice of poetic studies. And many foreign and Chinese scholars has already made relatively great progress in this respect although it is not great enough to propose poetic narratology for poetic scholars as well as poetic readers to guide their specific researching and reading practice of poetic criticism and promote a greater development for their poetic studies in combination with narrative studies as reviewed below respectively.

Firstly, narrative theories have been prosperous in western countries but the narrative theories with regards to poetic narratology have rarely been visited. Foreign narratologists have been devoting most of their time, energy and attentions to the narration in novelist texts while poetry the field that can present to readers most of human civilizations has been neglected by many narratologists.

On the whole, there are nine foreign scholars who have made a mention of the poetic narration in poetic narrative texts, with Iren J.F., DeJong, Claire Regan, Kinnery Monika Fludernik, Patrick Colm Hogan, Peter Hühn, Kiefer Jens as well as Brian Mchale included in this study. In an academic essay published in 1987, DeJong www.ijels.com made an exploration of the narrators and focalizers in the Iliad (DeJong Iren J.F., p1-5). Five years later, Kinnery tried to quest for the strategies of poetic narration by taking Chaucer, Spenser, Milton and Eliot as textual evidences in an essay Strategies of Poetic Narrative: Chaucer, Spenser, Milton, Eliot in 2003 (Kinnery Claire Regan,p1-10) At that time, the poetic narration in poetic narrative texts was not discussed quite often in poetic studies and narrative studies. The academic unawareness of foreign scholars in terms of the poetic narration in poetic narrative texts didn't go to a thorough end before the studies of Hogan came out in 2003 as he touched the narrative junctures in lyrical poems in one of his academic essays that is titled Extending the Theory: Emotional Prototypes, Narrative Junctures and Lyrical Poetry, which was collected in an anthology named The Mind and Its Stories: Narrative Universals and Human Emotions(Hogan Patrick Colm, p152-171) This was a great improvement of their narrative awareness in this respect. In fact, what can be seen from this improvement in a clear way is that the poetic narration in poetic narrative texts has been paid a given amount of attentions to by those two scholars.

More studies in this respect came out in 2005 because scholars like Fludernik, Hühn and Jens began to place more emphases on the poetic narration of the poetic lyrical texts in Medieval and early modern English poetry. Fludernik focused on the narration of medieval and early modern lyrical poems in English poetry in an essay collected in Theory into Poetry: New Approaches to the Lyric (Fludernik Monika, ed., by Müller-Zettelmann, Eva and Rubik, Margarete, p99-124). The most prolific scholar in 2005 was Hühn because he had published three essays to make his discussions in their respective ways firstly about the narrative forms of poetic texts in Plotting the Lyric: Forms of Narration in Poetry collected in Theory into Poetry: New Approaches to the Lyric (Hühn, Peter, ed., by Müller-Zettelmann, Eva and Rubik, Margarete, p147-172); secondly about the trans-generic narratology he proposed on the basis of a narratological analysis of lyrical poems in his essay titled Trans-generic Narratology: Application to Lyric Poetry in The Dynamics of Narrative Form: Studies in Anglo-American Narratology ( Hühn Peter, ed., by John Pier, p139-158); thirdly about the narrative analysis of lyric poems in his essay The Narratological Analysis of Lyric Poetry: Studies in English Poetry from the 16th to the 20 $0^{\text {th }}$ Century (Hühn Peter and Jens Kiefer, trans., by Alastair Mathews, p1-233).

In effect, what can be concluded from the studies of those scholars is that they have made some efforts to explore the poetic narration in poetic narrative texts as well as poetic lyrical texts and to some extent make some progress in promoting the further studies in this respect.

Page | 69 
Nonetheless, they have left later scholars some academic spaces in this respect because they haven't made enough efforts to theorize the poetic narration of poetic narrative texts. In McHale's terms, the major reason for this is that "some scholars specialize in narrative; others specialize in poetry; few specialize in both (McHale Brian, p12)". This situation hasn't been improving until an American famous narratologist named Mchale published on Narrative an essay titled Beginning to Think about Narrative in Poetry in 2009. In this essay, he proposed that the construction of poetic narratology should be taken into account in the following three folds in reference to the segementivity theory of Rachel Blau DuPlessis and the counter measured sengmentality of John Shoptaw in terms of lyricality and poeticity, segementivity and counter measurement, as well as war music(McHale Brian, p12-29).

In a sense, he was the first foreign scholar who proposed and explored the theorization of the poetic narration in poetic narrative texts because he thought that although some foreign scholars mentioned above had made some studies of the narrative poems composed by some poets like Homer, their studies hadn't been theorized in a systematic and profound way to construct poetic narratology in a real sense. What he had done was not only to find out the blind spots or limitations of their studies but also point out the fact that poetic narrative texts had been forgotten in narrative studies for ages. That was because he couldn't find out the traces in terms of the studies of poetic narrative texts whether in the studies collected in monographs or in the academic essays published on narrative journals. He owed this to the specialization of academic studies. He dealt with narrative scholars, poetic scholars and also that few scholars had carried out both poetic studies and narrative studies.

In his mind, the poetic narration in poetic narrative texts ought to be re-emphasized because "the majority of the world's literary narratives are poetic narratives (McHale Brian, p12)" After he published this essay in 2009, no foreign scholar came up with a single idea to define poetic narratology or to construct it. What was worse was that no successive academic progress was made since then. To some extent, poetic narratology continued to be ignored in western countries owing to the strong academic interest of foreign scholars in novelist narratology, prosaic narratology as much as dramatic narratology rather than poetic narratology.

Secondly, compared with what has been studied in both poetic studies and narrative studies in western countries, the Chinese narrative studies in regard to the theoretical construction of poetic narratology are relatively better than the similar studies in western countries. This can be certified in the following analyses grounded on the academic trends and developments in the field of western www.ijels.com narrative theories that are characterized with trans-genre, trans-discipline and trans-medium in terms of both horizontal and vertical dimensions due to the academic illumination from and the academic impact of the studies of post-classic narratology and pan-narratology on the narrative studies of contemporary western narratology carried out by Chinese scholars. To a great extent, the birth of poetic narratology is in consistent with the developmental needs of post-classic narratology in the light of trans-genre, trans-discipline and trans-medium.

On the whole, the successive studies of present Chinese narratology have already got close to Chinese dramatic texts and constructed a new narrative theory called dramatic narratology and its combination with novelist texts has formed novelist narratology; all those academic associations have witnessed of the academic formation trans-generic, trans-disciplinary as well as trans-medium narrative studies in Chinese narrative studies.

Later, Chinese narrative studies get close to filmic texts and shape filmic narratology, which has shorten the distance of narrative studies from musical texts and constructed musical narratology. At the same time, the association of narrative studies with narrative spaces leads to the formation of spatial narratology. Besides, the combination of narrative studies with other studies result in the establishment of a variety of other narrative theories ranging from feminist narratology, cultural narratology, ethic narratology, medical narratology, educational narratology, historical narratology, religious narratology, psychological narratology, commercial narratology, legal narratology cognitive narratology to rhetorical narratology and so forth. All those academic combinations with narrative studies have, to a great extent, been deepening and sharpening the marks transdisciplinary and trans-generic narrative studies in Chinese narrative studies.

In addition to trans-disciplinary and transa-generic narrative studies, the theoretical establishment of Chinese narratology has also taken form of trans-medium because of the emergences of advertisement narratology, journalist narratology, graphic and picturesque narratology, natural narratology, unnatural narratology, corporeal narratology (Bi-wu,Shang,p:99).

The appearances of those new theories have made Chinese narrative studies characterized with more and more properties of trans-medium narrative studies.

The leapfrogging academic development of Chinese narrative theories has constantly extended its academic boundaries into the narrative turns of trans-generic, transdisciplinary and trans-medium in succession. What needs to be improved is that Chinese narrative studies have much less to do with the poetic narration of poetic narrative texts. In other words, the narrative studies made of in China have also neglected their relevance to or

Page | 70 
relationships with poetic studies. Just as professor Tan Jun-qiang has put forward in one of his essays titled $O n$ the Narratological Studies of Lyrical Poetry: Poetic Narratology, "...for many years, the remarkable studies of contemporary narrative theories have seldom made a mention of poetry... (Jun-qiang Tan, p46)" It is this neglect that leads to the present passive situation of the theoretical studies in the field of poetic narratology.

Although many Chinese scholars haven't paid enough attentions to poetic narration, few of them have began to take into consider the construction of poetic narratology. The earliest mention of poetic narratology can be dated back to the following two studies made of by two Chinese scholars named Li Zang and Fei Jiang respectively. One is collected in an academic essay of the former titled Poetic Narratology in Memories: A Close Reading of A Watch Maker's Memories and the other in that of the latter under the title of Narration and the Intensity of Modern Chinese Poetry: The Argumentations of Textual Evidences and The Initial Thought of Constructing Poetic Narratology. The former pointed out the importance to make an analysis of poetic narrativity by taking $A$ Watch Maker's Memories as textual evidences in 1990s ( $\mathrm{Li}$ Zang, p54). Although the former didn't put forward the term poetic narratology definitely, the discursive implications in this essay had suggested it. In the similar way, the latter also made a study of poetry in order to construct a theoretical discourse of poetic narratology for the aim of widening the academic boundaries of Chinese narrative studies and dig out the unique insights for the narrative studies for modern Chinese poetry (Fei Jiang, p5).

After their studies, Bi-wu Shang published an academic essay under the title of Trans-generic Narrative Studies and the Construction of Poetic Narratology in 2012 due to the influential illumination he has acquired from an essay written by McHale under the title of Beginning to Think about Narrative in Poetry and the abundant narrative edifications he has benefited from his interview with David Herman as he mentioned in another of his academic essays titled The New Developments of Narratological Studies: An Interview with David Herman in 2009 (Bi-wu Shang, p98-105). In this essay, He has come up with three approaches to the construction of poetic narratology including the prosperous contexts of poetic narratology, the approaches to the construction of poetic narratology and the critical practices of poetic narratology (Bi-wu, Shang, p5). Any way, their studies made narrative studies have much more to do with poetic studies.

However, two things had to be mentioned and made clear. One was that although those essays have mentioned the term poetic narratology, they hadn't named it as Poetic Narratology in English. Bi-wu Shang has borrowed it www.ijels.com from McHale and termed it as narrative in poetry. The term poetic narratology was firstly translated into English by Jun Luo according to its Chinese equivalent. The other was that although the term poetic narratology has occurred to the minds of those scholars and although they had proposed the construction of poetic narratology, they haven't put their ideas into practices immediately. The thought of constructing poetic narratology wasn't put into practice until the publication of this essay under the title of Towards the New Realm of Western Narrative Theories: Poetic Narratology in which a systematic and scientific study of the narrative mechanism in narrative poems to re-examine the relationship between narratology and poetic studies, to construct poetic narratology and define it has been proposed in definite sense (Jun Luo, p81).

In the same year, four essays in this field including Towards the New Realm of the Studies of Poetic Narratology: On the Construction of the Narrative Grammar of Poetic Narration, A Cognitive Study of Poetic Narratology and On the Construction of Narrative Modes in Terms of the Fragementalization of Poetic Narratology Based on the Fragmentalized Narration of Modern Poetic Narrative Texts and On the Structuralist Interpretation of the Semantic Signs of Poetic Narration to the Textual Implications of Poetry were published in succession. In this way, "the construction of poetic narratology was firstly implemented by the respective induction and deduction of the textual structure and logic structure of poetic narrative texts as well as the diversity of the perspectives(Jun Luo, p103)" in order to propose and explore the narrative grammar of the theories of poetic narratology; secondly by the academic turn of the theoretical exploration of the developments of poetic narratology from the textual emphasis of poetic narrative texts to the relationship between those texts and their readers from the perspective of cognitive psychology... ( Jun Luo, p13); thirdly by the discussions about the theoretical construction of the narrative modes of the fragamentalization of poetic narration by taking modern poetic narrative texts as textual samples of poetic narratology in combination with the fragmented narration in modern poetic narrative texts (Jun Luo, p110); fourthly by means of the wider and deeper promotion of the transdisciplinary approaches to the theoretical studies of the poetic narrative texts in the theoretical exploration of poetic narratology from the perspective of structuralist narratology and the further exploration of the ways to promote the further developments and betterments of poetic narratology in terms of the interpretation of the semantic signs of poetic narration to the semantic implications of poetic narrative texts in four folds including the semantic signs of poetic narrative texts, the semantic implications of poetic narrative texts, the

Page | 71 
production or generation of the semantic implications of poetic narrative texts and the interpretation of the textual implications of poetic narration (Jun Luo, p99). It was in this case that the trans-disciplinary and trans-generic narrative studies and exploration of poetic narratology had been promoted to some extent.

It was in 2013 that four new breakthroughs had been found in poetic narratology.

The first breakthrough was the publication of the essay titled Argument against Narrative Imperialism: A Multidisciplinary Approach to Poetic Narratology in which the author argued with Brian Richardson over the so-called narrative imperialism by inspiring the scholars in the field of poetic narratology to try to abandon the platitude of narrative imperialism and continue to take a trans-disciplinary and a trans-generic approach to the studies of poetic narration (Jun, Luo, p79). This was because narratology had never seemed to be as inclusive as what had been criticized by narrative imperialism despite of its universality in almost all narrative texts; instead, it was making its way to a trans-the disciplinary and a trans-generic approach to narrative studies in poetic narrative texts with the theoretical support of the theoretical accomplishments in different disciplines, which was accepted as an inevitable way for any developing discipline and genres. It is unimaginable whether it is possible for a discipline and a genre to be developed in a closed rather than opened way or not at current. Therefore, poetic narratology has to be associated with the academic studies of cognitive psychology, philosophy and semiotics to set foot on its transdisciplinary and trans-generic studies in the process of constructing poetic narratology in the abstract sense.

The second breakthrough was the publication of the essay under the title of From Uncertainty to Certainty that had dealt with the relativity of the possible changes of the semantic implications in poetic narrative texts beginning with the structural changes of the internal signifiers, signified as well as their mutual relationship of semantic signs in those texts to arrive at the conclusion that the semantic implications of those poetic narrative texts were certain rather than uncertain. The views that considered them to be uncertain were grounded from a position of philosophical idealism and agnosticism (Jun Luo, Miao Xin, p11). What the studies of the semantic implications of poetic narrative texts ought to adhere to is a position of materialism instead of an idealist one that exaggerated the structural changes of the signifier, the signified and their mutual relationship in a one-sided way and takes it for granted that those changes were absolute changes instead of relative changes.

The third breakthrough could be seen from the publication of the essay titled An Exploration of the Desemanticized Narrative Mode of Poetic Narratology www.ijels.com from the Lexical Transformation of the Narrative Performative Verbs of the Poetic Texts of Narration. In this essay, an exploration of the desemanticized narrative modes of poetic narratology had been made respectively in the following four folds including the conception of the desemanticizaion of the implications of the poetic narration in poetic narrative texts, the qualities of narrative grammar in terms of the narrative performative verbs in the poetic narration of poetic narrative texts, the desemanticized narrative mode of the poetic narration in poetic narrative texts and the narrative performative verbs of poetic narration in poetic narrative texts (Jun Luo, ZhiminYang, p46).

The fourth breakthrough in this respect was typified by a prestigious scholar of Yunan University named Jun-qiang Tan due to his ongoing interest in the construction of poetic narratology after the successful publication of one of his academic essays under the title of On the Narrative Studies of Lyrical Poems: Poetic Narratology. In his terms, traditional narratology had ignored lyrical poems that didn't contain narrative constituents and put them aside the academic boundaries of narrative studies but this platitude had to be abandoned. For this sake, scholars began to make an analysis of and give an interpretation to lyrical poems in a narrative way. In addition, professor Tan still pointed out that poetic narratology as a subbrunch of narrative studies would start a new area for the studies of lyrical poetry and narratological theories (Junqiang, Tan, p119).

From then on, more studies in the field of poetic narratology have been made one after another as shown below in a temporal order according to the publication of these academic essays listed below from 2014 to 2016 .

In 2014, a general review on the development of poetic narratology has been finished in one of his academic essays titled Exploration and Expectation: a Review of the Studies in Poetic Narratology published in May, 2014 on the Journal of Changchun University of Technology to make a summary of the development of the theoretical studies of poetic narratology (Jun Luo, p98-100).

This essay has summarized the overall development of poetic narratology in addition to the new unpublished essays that might be acquired from the research projects applied by Jun-qiang Tan who has published his own monographs primarily in the field of narratology and secondarily poetic narratology.

In 2015, a new exploration of a detailed review on the development of poetic narratology has also been made after the publication of one of his academic essays titled On the Theoretical Construction of the Structural System of the Semiotic Atoms in the Semantic Signs of Poetic Narrative Texts on the Asian Journal of Social Science Studies, which extends the macro-studies of poetic narratology to its micro-ones (Jun Luo, Qing Yin, p39-47).

Page | 72 
In 2016, the publication of another academic essay titled Towards the Narrative Intertextuality in Poetic Narratology: An Intertextual Analysis of Lawrencian Birds, Beasts and Flowers on the World Journal of Social Science Research, proposing an idea of making an exploration of the narrative intertextuality in one of the poetic collection produced by D.H Lawrence (Jun Luo, Qin Liu, p22-43).

To sum up, one the one hand, despite the progress that has been made in the theoretical construction of poetic narratology based on their narrative explorations of poetic narrative texts, it hasn't been completely theorized, systematized and scientized, for the quantitative studies of the peoetic narration of poetic narrative texts in the theoretical construction of poetic narratology that have been closely related to the theoretical illumination of other disciplines haven't cropped up in succession in order to quicken and broaden the progression and process of the theorization, systematization, disciplinarization and scientization of poetic narratology from the perspective of structuralism.

On the other hand, neither the literary theorists nor the narrative theorists have ever given an elaborate definition to poetic narratology let alone come up with a theory for the poetic narration of poetic narrative texts with regard to the action of its story and its meaning as well as that of the poetic narrators of poetic narrative texts in the process of questing for the internal and intrinsic structural laws of the poetic narration in poetic narrative texts.

To tell the truth, what they have done is to generalize the narrative features in their specific practice of poetic studies from the perspective of narratology instead of making a dedicative exploration of the intrinsic structural mechanism in the textual construction of poetic narrative texts from the perspective of structuralism.

Therefore, it is significant for literary theorists all other the world to establish and develop poetic narratology for poetic studies and devote it to the reading and interpreting practices of poetic narrative texts for the parts of poetic readers, poetic scholars as well as poetic critics so as to dig out the intrinsic and objective laws that has been working in or out of relevant poetic narrative texts. In this case, the articulation of the objective mechanism of poetic narrative texts for the theoretical construction of poetic narratology from the perspective of structuralism is bound to be realized in a systematic, logic and scientific way, for everything that is inclined to be done in this respect is the academic efforts to be made to lay a solid foundation for the fulfillment of the aim of seeking for the eventual and successful establishment of poetic narratology grounded on the theoretical illuminations of structuralism.

\section{III.}

\section{THE THEORETICAL COMBINATION OF POETIC NARRATOLOGY WITH STRUCTURALISM}

There being the studies of the ingenious establishment as well as developments of novelist narratology, dramatic narratology, cinematic narratology or filmic narratology, spatial narratology as well as other types of narratology, no efforts in this respect have been made of to establish poetic narratology. Drawing on the very thoughts of the logicization, systematization and scientization that can be adopted to promote the poetic narration in poetic narrative texts, this essay will try to justify the narrative postulation that poetic narratology ought to be established to enrich the theories of both narrative studies and poetic studies from the perspective of structuralism.

For the sake of the basic requirements explicated above, the major narrative postulation proposed above will be likely to be enlightened and justified in the theoretical analyses and argumentations of this study according to the light thrown in structuralist narratology in terms of narration, story and discourse in accordance with the three narrative levels divided by Gérard Genette.

\subsection{The Structuralist Definition of Narration}

According to structuralist narratology, narration refers to two parts of a narrative process, the first part of which has much to do with the narrative action and the second the narrative event. Therefore, narration contains narrating and events, in other words to represent what happens in a given time and space by means of language or other media grounded on the consideration of the causes and effects of at least two events (Sommer, Roy,p120), which can be either factual or fictional. And structuralist narratology also divides narration into at least seven levels including narrative perspectives, narrator, narratee, narrative time, narrative space, narrative forms, and narrative functions (Ya-min $\mathrm{Hu}, \mathrm{p} 18-85$ ). This thesis will make a study of those six levels of narration in details in poetic narrative texts to make a distinction of poetic narration from novelist distinction in a trans-generic way to tell poetic readers that poetic narration is different from novelist narration, dramatic narration and prosaic narration. The specificity or particularity of poetic narration with regards to the perspectives of poetic narration, the narrator of poetic narration, the narratee of poetic narration, the narrative time of poetic narration, the narrative space of poetic narration, the narrative forms of poetic narration and the narrative functions of poetic narration in poetic narrative texts will be one of the focuses of this study that needs great efforts to be made if it will have been finished. 


\subsection{The Structuralist Interpretation of Story}

The studies of story in structuralist narratology cover the exploration of and discussion about the plot, character, environment, grammar and events of novelist narration.

First of all, the studies of novelist plot narration often borrow the ideas from Aristotelian plot, traditional plot and classic plot to make an analysis of properties of the specific plot of the specific novelist texts. This study will generalize the universal laws of poetic plot after a series of comparisons of the constituents in poetic plot with those of novelist plot, prosaic plot and dramatic plots on the basis of the textual analyses of the poetic narrative texts selected from American literature as textual samples.

Secondly, as for the characterization, this study will make a contrast of novelist characterization with poetic characterization in reference to the theories related to the theories of characterization in structuralist narratology proposed by Seymour Chatman, Vladimir Propp, Etienne Sourian, A.J. Greimas, E.M. Foster, Joseph Ewen and Roland Barthes.

Thirdly, the discussion of novelist environment in poetic narration and the exploration of poetic environment in poetic narration will be interwoven in this study due to the mutual similarity and differentiality in terms of symbolic environment, neutral environment and ironic environment in poetic stories.

Fourthly, the narrative grammar of poetic narration will be discussed on the basis of a good understanding of the theoretical claims offered by Vladimir Propp, Tzvetan Todorov and Levi Strauss.

Fifthly, the specific discussion of the narrative events in the poetic narration of poetic narrative texts will be compared with those of the dramatic narration in dramatic narrative texts, the prosaic narration in prosaic narrative texts and the novelist narration in novelist narrative texts in reference to the theories of narrative events proposed by Seymour Chatman.

\subsection{The Structuralist Interpretation of Narrative Discourse}

On the whole, the structuralist analysis of narrative discourse was proposed by Gérard Genette just as explained in this essay in consistence with the lights thrown by the theoretical insights of him and Ya-min $\mathrm{Hu}$. On the one hand, in his terms, narrative discourse can fall into five folds including narrative order, narrative duration, narrative mood and narrative voice just as what will be explicated in the theoretical justification of the narrative discourse in the poetic narration of poetic narrative texts. Therefore, this study will continue to discuss the narrative order of poetic narration, the narrative duration of poetic narration, the narrative mood of poetic narration and the narrative voice of poetic narration in the poetic narration of poetic narrative texts. On the other hand, considering the concrete practicality of the discursive mode (proposed by $\mathrm{Ya}$-min $\mathrm{Hu}$ ) in the theoretical construction of the narrative discourse in the poetic narration of poetic narrative texts, this study will not devote a given textual spaces to explore and elaborate it in details, for what this study will make its way to is the possibility of whether the narrative discourse exist in the poetic narration of poetic narrative texts or not.

Given that the loose relationship between the narrative discourse and the discursive modes of the poetic narration in poetic narrative texts, this study will attach a great importance on the elaboration of the narrative discourse in the poetic narration of poetic narrative texts rather than the profound exploration of the discursive modes of the poetic narration in poetic narrative texts in line with the "direct speech, indirect speech, free direct speech and free indirect speech (Ya-min, Hu, p18-85)".

\subsection{The Structuralist Interpretation of Non-narrative Discourse}

The structuralist analyses of non-narrative discourse refer to the narrator's understanding of or comments on the novelist story of novelist narrative texts by the virtue of narrative events, environments and characters in accordance with relative narrative theories of structuralist narratology. Generally, non-narrative discourse can fall into three categories including covert comments, overt comments and mixed comments made by narrators either directly or indirectly (Ya-min, Hu, p103). This study will firstly explore the covert comments, secondly the overt comments and finally the mixed comments of the narrator in the poetic narration of poetic narrative texts produced by narrative poets in consistence with what has been formulated in non-narrative theories in combination with the specific quality of the texts.

\section{THE STRUCTURAL CONSTRUCTION OF POETIC NARRATOLOGY}

\subsection{The Structuralist Construction of Poetic Narration} in Poetic Narrative Texts

In the light of the theoretical construction of the poetic narration in poetic narrative texts from the perspective of structuralism, what ought to be done in the first place is to give a definition of the poetic narration in poetic narrative texts in reference to the definition of the narration of narrative texts by comparing with each other to find out the universality as well as specificity between the poetic narration of poetic narrative texts and the narration of narrative texts, for this narrative comparison between them has been characterized with conclusion that there are a series of explicit distinctions that can be found out among the poetic narration in poetic narrative texts, the 
prosaic narration in prosaic narrative texts, and the dramatic narration in dramatic narrative texts respectively in accordance with the traditional division or demarcation of the frequently-mentioned literary genres in the theoretical studies and practical applications of traditional literary theories and modern literary theories based on a good understanding of the essential or ontological differences of one literary genre from another just as what has been listed afore.

What ought to be firstly proved in the theoretical foundation of poetic narratology from the perspective of structuralism is that just as what has been frequently mentioned and analyzed in the narrative studies of by many narratologists in the process of making a sharp comparison of the specific narration in one of the four major literary genres with that in another of them, the poetic narration in poetic narrative texts also contains appropriate narrative actions and narrative events that are also likely to be used to tell, to represent and predict what has happened in the past temporal fragments, what is happening in present temporal fragments and what will happen in the future temporal fragments according to the temporal clues of a given poetic story in a given time and space in poetic narrative texts by means of putting the particular narrative language into the textual production in poetic narrative texts grounded on the very kind of ingenuous consideration of the causes and effects of at least two events that can be either factual or fictional.

Of course, the fulfillment of the logical, theoretical and practical justification of the narrative proposition here requires firstly the reasonable elaboration of the logical relationship between one of the narrative actions and another of them as well as between one of the narrative events of them and another of them as far as the poetic narration of poetic narrative texts is concerned in the logical construction of poetic narratology step by step because this logical relationship between either two of them is likely to be served as the logical evidences for the logical justification of the narrative proposition explicated above.

What it secondly requires is the theoretical justification of the feasibility to combine narrative theories with the specific narrative actions and the narrative events in the narrative design of the textual production of poetic narrative texts, which can serve as part of the theoretical evidences that are likely to play an important role in the theoretical justification of the same narrative proposition stated above.

The third thing that has to be required in the practical justification of the same narrative proposition discussed above time and time again is that the textual collection, categorization and integration based on a number of conspicuous choices that have to be made in the process of finding out the proper textual samples in poetic www.ijels.com narrative texts, for those textual samples ought to be accepted as part of the textual evidences that are likely to indicate the cares that have been taken of in the practices of textual production of narrative poets in order to finish the complete and specific practical proposition of the narrative proposition of this essay.

What ought to be secondly proved in the theoretical foundation of poetic narratology from the perspective of structuralism is that the particular poetic narration of poetic narrative texts in the construction process of poetic narratology ought to be thought of as a systematized theory of poetic narration that has been composed of at least seven major narrative factors as explained below one after another.

The first major narrative factor of this poetic theory named poetic narratology is the narrative perspectives the poetic narration in poetic narrative texts which is made up of perceptive perspective and cognitive perspective (Yamin Hu,p23) in accordance with the specific explanation that has been made to in the similar narrative framework of the novelist narration in novelist narrative texts that are likely to be seen as a set of narrative mirrors for the narrative analyses of the poetic narration in poetic narrative texts.

The second major narrative factor of this poetic theory named poetic narratology is the narrator in the poetic narration of the poetic narrative texts that are likely to bear great similarity to that in the novelist narration of novelist narrative texts after having made an ingenuous comparison with what is like in novelist narrative texts in terms of the internal focalization of an internal narrator, the external focalization of an external narrator as well as the zero focalization of an omniscient narrator who have been omnipresent and omnipotent in the whole textual spaces of the poetic narrative texts.

The third major narrative factor of this poetic theory named poetic narratology is that the narratee of the poetic narration has been turned out to be able to have a possible talk with the narrator of the poetic narration in poetic narrative texts in the form of narrating the factual events or fictional events, narrating mysterious events in fairy tales or narrating the supernatural events in surrealist context if it is the case with poetic narrative texts based on the correspondent responses the narratee has given to the narrator who has been performing his narrative functions in a specific narrative events of a poetic story.

The fourth major narrative factor of this poetic theory named poetic narratology has much to do with the narrative time of the poetic narration in poetic narrative texts, for the temporal structure, order as well as configuration of the narrative time bear few similarities with those in novelist narrative texts. The former might be articulated in an explicit way while the latter implied in an implicit way, which can not but be perceived by an

Page | 75 
intelligent readers who are believed to be sensitive for the implicit way of the temporal articulation implied in a certain word that is characterized with temporal qualities. The fifth major narrative factor of this poetic theory named poetic narratology is greatly concerned with the definition and demarcation the narrative space of the poetic narration in poetic narrative texts in comparison with the spatial definition and demarcation of narrative spaces in other narrative texts in terms of the story space, discursive space, the discursive space, the imaginative space, the contextual space, as well as the associative space of the poetic narration in poetic narrative texts in a distinctive way according to the spatial qualities of the narrative spaces in poetic narrative texts rather than follow suits with the routines repeated time and time again in the narrative studies of other narrative texts whose differences from poetic narrative texts depend much on the genrological qualities in reference to the differential marks of the categorical rules in literary genrology.

The sixth major narrative factor of this poetic theory named poetic narratology centers on the narrative forms of the poetic narration in poetic narrative texts in the form of biographical narration, autobiographical narration, captive narration, epical narration, allegorical narration, mysterious narration, empirical narration, introspective narration, retrospective narration, historical narration, legendary narration, nostalgic narration, report-styled narration, linearly narration, non-linearly narration, fictional narration, factual narration, dramatic narration and so on, for the same narrative events in a poetic narrative texts can be articulated or voiced in a variety of narrative forms according to the narrative intention or motivation of the narrator of poetic narrative texts manipulated by narrative poets who are likely to be regarded as the ruler of the narrative world of their own poetic narrative texts in the process of their textual production as well as narrative construction.

The seventh major narrative factor of this poetic theory named poetic narratology is closely relevant to the poetic narrators' functions in poetic narration of poetic narrative texts that can be categorized in a respective way as the narrative functions, the organizational functions, the observational functions, the commentary functions, the communicative functions as well as the recording functions of the poetic narrators in poetic narrative texts in consistence with the specific narrative construction or configuration of objective intentions as well as subjective intentions of the narrators of the poetic narrative texts who have frequently been determined, dominated or manipulated by the omniscient manipulation of the poetic narrators either in an explicit way or an implicit way.

To sum up, each narrative factor of the poetic narration in poetic narrative texts is a sub-narrative construction of the www.ijels.com poetic narration of poetic narrative texts that ought to be regarded as an organic constituent of the specific theoretical system of poetic narratology concerning the poetic narration of poetic narrative texts, for each of them have been playing an important role in the textual construction of the poetic narration of poetic narrative texts in the process of finishing its corresponding narrative given task that is designed to give a narrative presentation to the poetic readers of poetic narrative texts the entirety of the whole poetic stories of the poetic narrative texts. This is why those narrative factors have been chosen to be as the theoretical evidence for the theoretic justification of the first part of the narrative proposition of this essay in addition to the textual evidences to be collected from the textual samples that ought to be regarded as analytical samples in criticizing practices of poetic narrative texts and empirical evidences acquired from the narrative illuminations gained from the reading experiences of poetic narrative texts in the reading practices of poetic narrative texts, which will be likely to be elaborated in the textual justification of poetic narratology in the process of the textual analyses of the specific poetic narrative texts.

\subsection{The Structuralist Construction of Poetic Stories in Poetic Narrative Texts}

In the case of the theoretical construction of the poetic stories in poetic narrative texts from the perspective of structuralism, the specific justification of the narrative proposition of the poetic story in poetic narrative texts ought to be primarily based on a variety of illuminative discussions, profound analyses, valuable explorations, insightful generalizations as well as systematic summaries of the intrinsic constructive laws of the poetic stories in poetic narrative texts for the aim of seeking for the constructive mechanism in the textual construction of the poetic narrative plots, poetic narrated characters, poetic narrative environments, poetic narrative grammars and poetic narrative events one after another by making a good comparison with the constructive mechanism in the practical textual construction of the novelist narrative plots, novelist narrated character, novelist narrative environment, novelist narrative grammar and novelist narrative events of the construction of the novelist stories in novelist narrative texts grounded on a series of sample stories that can be treated as the textual evidences for the theoretical justification of the poetic stories of the poetic narration in poetic narrative texts just as explicated in the following five folds.

The first fold that needs to be paid a careful attention to at the outset of the theoretical construction of the poetic stories in poetic narrative texts from the perspective of structuralism is to make a structural explorations of the poetic plots in poetic narrative texts by means of 
generalizing the universal and ubiquitous internal laws and mechanism in terms of the structural formation, construction as well as configuration of the poetic plots in the poetic narration of poetic narrative texts that have been grounded on a series of comparisons is to likely to be made of between either two of the structural constituents existing in the poetic plots of poetic narrative texts with those of the novelist plots in novelist narrative texts, those of the prosaic plots in prosaic narrative texts and those of the dramatic plots in dramatic narrative texts in reference to the lights that are to be thrown on the theoretical plots from the perspective of structuralism with regard to the structural of stories in narrative texts.

After making an overall comparison of the structural superiority and inferiority of the structural constituents of the poetic plots in poetic narrative texts with those superiority and inferiority of the respective stories with the novelist plots in novelist narrative texts, those of the prosaic plots in prosaic narrative texts and those of the dramatic plots in dramatic narrative texts in reference to the illumination from Aristotelian plot, traditional plot and classic plot, what ought to be done in this respect is that a series of textual samples ought to be selected from poetic narrative texts to make a textual analysis of them for them aim of seeking for the structural mechanism of in the specific construction of the poetic stories in poetic narrative texts and simultaneously seeing if the theoretical construction of the poetic stories in poetic narrative texts is feasible according to the practical texts of the textual analyses of those textual samples taken from poetic narrative texts.

The second fold that needs to be paid a careful attention to in the process of the theoretical construction of the poetic stories in poetic narrative texts from the perspective of structuralism is to make a structural analyses of the poetic characterization in the poetic narration of poetic narrative texts by making an overall contrast with the novelist characterization of the novelist characterization in novelist narrative texts, the prosaic characterization of the prosaic narration of prosaic narrative texts and the dramatic characterization of the dramatic narration in dramatic narrative texts respectively in the comparative process of the personalities, habits, attitudes, values, views, motivations, insights as well as behaviors of the characters in those texts.

What ought to be emphasized is that one the one hand the comparative analysis has to be made of in reference to the narrative theories in the light of the characterization in narrative texts enlightened by the structuralist narratology proposed by Seymour Chatman, Vladimir Propp, Etienne Sourian, A.J. Greimas, E.M. Foster, Joseph Ewen and Roland Barthes while on the other hand, this comparative analysis ought not to be reduced to the edification of those theoretical insights, for the role that the comparative www.ijels.com analysis ought to play in this textual comparison is to enrich the narrative theories related to the characterization in different narrative texts in more than one fold rather than be lost in the labyrinths that have been interweaved in the theoretical imitation of the theoretical limitations of structuralism owing to the ignorant and blind admiration for the scaring authoritative glories of those structuralist narratologists step by step regardless of the academic omission of a narrative scholar in terms of seeking for narrative truth in the poetic characterization of the poetic narration in poetic narrative texts.

The third fold that needs to be paid a careful attention to in the process of the theoretical construction of the specific poetic stories in poetic narrative texts from the perspective of structuralism is to make an exploration of the constructive mechanism in the structural construction of poetic narrative environments in the poetic narration of poetic narrative texts by the valuable clarification of the interweaving and overlapping mechanism of the poetic narrative environments in the theoretical construction of the poetic narration in poetic narrative texts in reference to that in the intrinsic mechanism of the novelist narration in novelist narrative texts, the prosaic narration in prosaic narrative texts as well as the dramatic narration in dramatic narrative texts by taking into account the mutual similarity and differentiality in the light of the symbolic environment, neutral environment and ironic environment in the poetic narration of the poetic stories told in poetic narrative texts.

In a simultaneous way, what has been acquired from the profound theoretical exploration of the mechanism in the poetic narrative environment of the poetic narration in poetic narrative texts also has to be tested in the analytical practices of the textual analyses of the poetic narrative environment of poetic narrative texts to figure out the theoretical feasibility of what has been dug out in the analytical experiment and experimental results of the textual samples of poetic narrative texts in reference to the theoretical explication of the narrative contexts in the novelist narration of novelist narrative texts owing to its typicality.

The fourth fold that needs to be paid a careful attention to in the process of the theoretical construction of the specific poetic stories in poetic narrative texts from the perspective of structuralism is to look for the system of symbols as well as rules that has been playing an important role in constituting, governing or ruling the basic narrative mechanism as well as narrative mode of poetic narrative texts in an organic way, a complete way and a scientific way for the aim of having a good understanding of the superficial structure and profound structure of the poetic narration in poetic narrative texts in the process of analyzing and generalizing the validity as well as diversity of the basic narrative structures. 
If necessary, this can be done on the basis of a good understanding and analysis of theoretical claims in the light of the narrative grammars offered by Vladimir Propp, Tzvetan Todorov and Levi Strauss respectively in the process of their analyzing the narrative grammar in the narrative grammar of the novelist narration in novelist narrative texts.

That is because with the help of the structuralist linguistic grammar rather than pedagogical grammar that has been coincidently imitated by the narrative grammar of structuralist narratology in the narrative exploration of the novelist narration of the novelist narrative texts, it is more conducive to build the narrative grammar of poetic narration in poetic narrative texts that can be termed as poetic narrative grammaticism in poetic narrative texts in accordance with the logical relationship between the either two specific narrative components of the narrative mechanism and narrative modes in a logical fashion as far as the basic poetic narrative grammar of poetic narrative texts is concerned.

What matters more in this structural construction of the poetic narrative grammar is that the construction process of this narrative grammar as mentioned above ought to be rooted in the textual evidences in the form of textual samples found out and picked out from poetic narrative texts in order to act as the practical evidences supported by the grammatical mechanism, grammatical rules, structural configuration as well as grammatical structures existing in the textual samples or fragments of poetic narrative texts, which ought to be used to tell the feasibility of the theoretical discoveries and findings in the analytical practices and critical practices of the grammatical mechanism, grammatical rules, structural configuration as well as grammatical structures.

The fifth fold that needs to be paid a careful attention to in the process of the theoretical construction of the specific poetic stories in poetic narrative texts from the perspective of structuralism is to compare the narrative events to be defined and applied in the poetic narrative events of poetic narrative events with those of dramatic narrative texts, prosaic narrative texts as well as novelist narrative texts in accordance with the important views, conceptions as well as insights one after another in terms of the particular arrangement of the narrative events in poetic narrative texts, the specific distribution of the narrative events in poetic narrative texts, as much as the structural configuration of the poetic narrative texts in regard to the appropriate narrative theories that have been placing an vital emphasis on the very kind of narrative events that have been proposed by Seymour Chatman in an analogical way in order to highlight the particularity of the narrative events in the poetic narration of poetic narrative texts.
One thing to be stressed in this regard is that the comparison explained above ought to be associated with the experimental analyses of the textual experiments that have been purposefully designed and carried out to tell the reasonability of the experimental results related to the relevant theoretical generalizations, theoretical analyses, theoretical judgments, theoretical inferences as well as theoretical summaries of the structural foundation of the narrative events that have been designed in the textual production of poetic narrative texts from the perspective of structuralism.

To be brief, it is likely to construct the poetic stories of the poetic narrative texts based on the discussions focused one by one on the poetic plots, poetic characterizations, poetic narrative environments, poetic narrative grammars as well as the poetic narrative events of poetic narrative texts owing to the organic combination of the theoretical explorations based on the theoretical lights thrown by structuralism with the practical applications designed to test the values of the theoretical findings, for the former can provide valuable illuminations for the latter and the latter theoretical revisions and promotions for the former in a reciprocal way.

\subsection{The Structuralist Construction of the Narrative Discourses in the Poetic Narration of Poetic Narrative Texts}

In the case of the specific justification of the theoretical construction of the narrative discourse in the poetic narration of poetic narrative texts, it ought to be based on the succinct justification of the following theoretical proposition of the justification of the narrative discourse in poetic narrative texts except for the justification of discursive modes in poetic narrative texts in a respective way.

On the one hand, since narrative discourse can fall into five folds including narrative order, narrative duration, narrative frequency, narrative mood and narrative voice (Genette, Gérard, p33-212), it takes five steps to finish the succinct justification of the theoretical construction of narrative discourse in the poetic narration of poetic narrative texts namely the succinct justification of the theoretical construction of the narrative order in the poetic narration of poetic narrative texts, the succinct theoretical justification of the theoretical construction of the narrative duration in the poetic narration of poetic narrative texts, the succinct justification of the theoretical construction of the narrative frequency in the poetic narration of poetic narrative texts, the succinct justification of the theoretical construction of the narrative mood in the poetic narration of poetic narrative texts and the succinct justification of the theoretical construction of the narrative voice in the poetic narration in poetic narrative texts in associations with the textual evidences that are likely to be found out

Page | 78 
and viewed as persuasive analytical samples in poetic narrative texts.

The succinct justification of the theoretical construction of the narrative order in the poetic narration of poetic narrative texts is to make a study of the anachronics in the poetic narration of poetic narrative texts that is likely to be extended into the future, to be retreated to the past and to be kept at the present including the reach, extent, analepses and prolepses. In the first sense, it can be separated from either moment of the story. In the second sense, according to the narrative clue of the poetic story in poetic narrative texts, these temporal distances can be named as the reach of anachronics. The anachronics itself is also likely to cover a long or short duration of story termed as the extent of anachronics. In the third sense, the analepses of anachronics has fallen into four groups including the external analepses, the internal analeoses, the complete analepsis and the partial analepsis according to the following five explanations that will be made to this point.

The first explanation to be made to this point is that the external analepses are external, for they will never interfere with the first narrative at any moment. The role it has played in the poetic narration of poetic narrative texts is to illustrate one or another antecedent for the readers.

The second explanation to be made to this point is that the internal analepses are different because their temporal field is embraced in the temporal field of the first narrative, which is likely to result in narrative redundancy and collision in the poetic narration of poetic narrative texts.

The third explanation to be made to this point is that the complete analepses in the poetic narration of poetic narrative texts will likely to be connected with the first narrative without a single gap between the two sections of the poetic story in the poetic narration of poetic narrative texts.

The fourth explanation to be made to this point is that the partial analepses in the poetic narration of poetic narrative texts will not put a stop to an ellipsis without one more connection with the first narrative.

The fifth explanation to be made to this point is that the prolepses in the poetic narration of poetic narrative texts embrace internal prolepses, external prolepses, complete prolepses and repeat prolepses. Among them, the role external prolepses is likely to play in the poetic narration of poetic narrative texts is to translate the narrative action into its logical conclusion as the epilogues in the poetic narration of poetic narrative texts will be affected by that of the internal prolepses to owing to the role that has played in the present interference of the specific narrative action of the poetic narration in poetic narrative texts. (Gerald Genette, trans. by Rong-wen Wang, p33-85) www.ijels.com
The succinct theoretical justification of the theoretical construction of the narrative duration in the poetic narration of poetic narrative texts refers to making a study of the isochronism and narrative in terms of temporal summary, ellipsis, pause and scene in the poetic narration of poetic narrative texts in accordance with the following four elaborations.

For the part of the first elaboration, when the story time of the poetic narration in poetic narrative texts is zero and the pseudo-time of the poetic narration in poetic narrative texts equal to $n$, it is usually called as the temporal pause of the poetic narration in poetic narrative texts. When the pseudo-time of the poetic narration in poetic narrative texts is equal to story time, it is called as the temporal scene of the poetic narration in poetic narrative texts. When the pseudo-time of the poetic narration of poetic narrative texts is lesser than story time, it is called as the temporal summary of the poetic narration in poetic narrative texts. When the story time of the poetic narration in poetic narrative texts is $\mathrm{n}$ and the pseudo-time of the poetic narration of poetic narrative texts equal to zero, it is usually called as the temporal ellipsis of the poetic narration of poetic narrative texts. So to speak, the temporal summary of the poetic narration in poetic narrative texts is brief, and the short temporal summary briefer than the poetic description in poetic narrative texts. The fundamental rhythm of the poetic narration in poetic narrative texts is determined by the temporal scene and alternation of the temporal summary of the poetic narration in poetic narrative texts. A lot of poetic descriptions in the poetic narration of poetic narrative texts are no more than the poetic iterations of the poetic narration in poetic narrative texts. In other words, they have nothing to do with a particular moment in the poetic narration of poetic narrative texts but have something to do with a series of analogous moments in the poetic narration of poetic narrative texts. Thus, it can be inferred that the poetic description of the poetic narrative texts can not necessarily cause the temporality of the story in the poetic narration of poetic narrative texts to the effect that the poetic description in the poetic narration of poetic narrative texts is not a temporal pause of the poetic narration in poetic narrative texts.

In the case of the second elaboration, the temporal ellipsis includes narrow ellipsis and time ellipsis. From the point of view of the narrative time of the poetic narration in poetic narrative texts, the temporal analysis of the temporal ellipses in the poetic narration of poetic narrative texts is the temporal analysis of the story time elided in the poetic narration of poetic narrative texts.

On the part of the third elaboration, the temporal ellipsis in the poetic narration of poetic narrative texts includes the explicit temporal ellipses of the poetic narration in poetic narrative texts and the temporal implicit ellipses in

Page | 79 
poetic narrative texts. The former ones are often regarded as the succinct temporal summaries while the later ones can just be inferred from some chronological lacuna or gap in the narrative continuity of the poetic narration in poetic narrative texts. Moreover, the most implicit form of the temporal ellipsis in the poetic narration of poetic narrative texts is the purely hypothetical ellipsis.

As far as the last elaboration is concerned, each temporal scene in the poetic narration of poetic narrative texts has been characterized with the inaugural value of the narrative event of the poetic story in poetic narrative texts, for it has marked the temporal entrances of the protagonist of the poetic story in poetic narrative texts into a new place where poetic readers ought to have expected too much. (Gerald Genette, trans. by Rong-wen Wang, p86-108)

The succinct justification of the theoretical construction of the narrative frequency in the poetic narration of poetic narrative texts is concerned with making a study of the frequency relations between the poetic narration and the diegesis in the poetic narration of poetic narrative texts in the light of the singulative narration and iterative narration, determinative narration, specific narration, extensive narration, internal and external diachrony, alternation and transitions in the poetic narration of poetic narrative texts.

From the point of view of the narrative frequency in the poetic narration in poetic narrative texts, what Genette holds is worth taken into account by taking it from him that whatever the poetic narration of a poetic narrative is, it may tell once what happened once and $n$ times what had happened $\mathrm{n}$ times in a respective fashion, which is called as the singulative narration in the poetic narration of poetic narrative texts; if the poetic narration of the poetic narrative texts tells once what happened $\mathrm{n}$ times, it is called as the iterative narration in the poetic narration of poetic narrative texts; if the poetic narration of the poetic narrative texts tells $\mathrm{n}$ times what happened once, it is called as repetitive narration in the poetic narration of poetic narrative texts.

However, judging from the narrative functions of the poetic narration in poetic narrative texts in an interactive way, the iterative narration in the poetic narration of poetic narrative texts will almost subordinate to the singulative narration of the poetic narration in poetic narrative texts, for it is much more inevitable for the latter to be affected by the former. That is because relatively speaking, the narrative events in the poetic narration of poetic narrative texts are obviously are less permanent than those in novelist narrative texts. It is for this case that the determinative narration of the narrative series in poetic narrative texts are generally defined by the indication of the specific narration in terms of the beginnings and their ends of those narrative series. Hence, www.ijels.com this determination process in the poetic narration of poetic narrative texts tends to be indefinite.

In addition, the specific narration in the poetic narration in poetic narrative texts also remains indefinite without some remarkable adverbs like sometimes, certain days, often, etc. That is because in the light of Genette, the narrative rhythm of the poetic narration in poetic narrative texts depends much on the alternation between the iterative and singulative narration in the poetic narration of poetic narrative texts because there are three types of iteration (Gerald Genette, trans. by Rong-wen Wang, p113-145). In fact, if they are generalizations in the poetic narration of poetic narrative texts that are concerned with general facts also existing outside of the fibula, they will get very close to the situational descriptions in poetic narrative texts. If it is the case, this iteration ought to be termed external iteration. (Miek Bal, p112-113)

The succinct justification of the theoretical construction of the narrative mood in the poetic narration of poetic narrative texts deals with the narrative mood that is composed of the narrative events, narrative words, narrative perspectives as well as narrative focalizations in the poetic narration of poetic narrative texts as analyzed in the following five respects.

First of all, the function of the narrative mood in poetic narrative texts is to tell a story and to report the authentic fact of the story as it happens. In the strict sense, the epitomized function of the narrative mood in this regard can be characterized with its indicative properties. In the literal sense, the word "mood" means to affirm relevant things to different extents, for different forms of the verb have been used to describe things from different angles. While telling a story in the poetic narration of poetic narrative texts, one can tell more or less and can tell from one point of view or another. The two chief modalities of the narrative regulation regarding narrative information in the poetic stories in poetic narrative texts are narrative distance and perspective respectively.

Generally speaking, if the poet does speak in his own name and make his readers believe that he is the speaker, it is pure narration. On the contrary, if the poet tries to tell his readers that he does not speak, that is imitation. The distance between narration and event is greater than that between narration and imitation because pure narrations are characterized with indirection and condensation. Their contents are more succinct and their narrative ways more indirect.

Secondly, whatever its mode is, the narrative events in poetic narrative texts are narrative because they have recorded the verbal narration of poetic narration in poetic narrative texts by using non-verbal narration. In this sense, the imitation in the narration of those texts will just be nothing but the illusion of imitation. It depends on the relationship between the message sender and the message

Page | 80 
receiver of the narration in the practical narrative contexts. To this extent, the imitative factors of poetic narrative texts are composed of two aspects. One is the quantity of narrative information. The other is the absence of the informer, for his presence is just a way of story telling that requests the poetic narrator to present the content of narration as much as he can with no traces of telling that he has left in the poetic narration. Accurately speaking, what the narrator is required to do is try to make the readers forget that he is telling stories. What needs to note in the poetic narration of poetic narrative texts is that two essential principles of his narrative presence including the Jemesian dominance of specific scene and the Flaubertian transparency of the narrator in the poetic narration of poetic narrative texts. They ought to be followed because one principle of those two principles is closely related with another.

Thirdly, it can be seen clearly that the definition of the narrative mood in the poetic narration of poetic narrative texts is concerned with a temporal determination and an inverse relationship between the informational quantity and narrative speed of the poetic narration, for it is also involved in a phenomenon of voice and the degree of narrating instance's intervention. The ambivalence of this is that the narrative mood in the poetic narration of poetic narrative texts is almost made up of all singulative and iterative scenes when the poetic narrator in those texts occurs frequently in the poetic narration. That is because the narrator in poetic narrative texts has been acting as the source, the guarantor, the organizer, the analyst, the commentator, and especially the producer of metaphor in the poetic narration of poetic narrative texts.

Fourthly, the temporal distance between the story and the narrating instance in the poetic narration of poetic narrative texts will not lead to the modal distance between the story and the narration. The mimetic illusion neither disappears not weakens.

Fifthly, the narrative words in the poetic narration of poetic narrative texts are absolute imitations. There is no difference between the statement in the text and the words uttered by the protagonist. It is just the transition from the oral language of real live to the written one in the poetic narration of poetic narrative texts. Sometimes, it is very difficult to distinguish what words are in the poetic narration in poetic narrative texts from what are gesture, posture and state of mind in the real lives of the poetic narrator. There is no doubt that the progressive push can further be reduced as narrative events. (Gerald Genette, trans. by Rong-wen Wang, p161-211)

The succinct justification of the theoretical construction of the narrative voice in the poetic narration in poetic narrative texts refers to the narrative voice that involves the narrating instance, the narrating time, the narrative levels, the metadiegetic narrative, the metalepses, the www.ijels.com persona, the narrator, the functions of the narrator as well as the narratee respectively in the theoretical foundation of the narrative voice in the poetic narration of poetic narrative texts as exemplified one after another in the following four theoretical analyses.

The first analysis of the narrative voice in the poetic narration of poetic narrative texts begins with the definition that narrative voice in the poetic narration of poetic narrative texts refers to the relationship between action and the subject in the progression of the narrative events in poetic stories designed in poetic narrative texts. The subject is not only likely to be the one who completes or undertakes the narrative action, but also the one who reports it. As a matter of fact, it is likely to include all those who have taken part in the narrating activity in the narrative progression of the poetic stories throughout the narrative chains that have run through the whole plot of the poetic stories told in poetic narrative texts.

The second analysis of the narrative voice in the poetic narration of poetic narrative texts primarily deals with the categorization of the narrating time in the poetic narration of poetic narrative texts including narrating, subsequence, priority, simultaneousness and interpolation respectively in accordance with the coincident overlaps or paralleled continuation between one of the narrative event of the poetic stories in poetic narrative texts with another of them, which also invites the textual elaboration in the textual samples that can be regarded as the textual evidences for the enrichment and betterment of the theoretical justification of the narrative voice in the poetic narration of poetic narrative texts.

The third analysis of the narrative voice in the poetic narration of poetic narrative texts has much to do with the definition of the narrative levels in the specific narrative action of the specific narrative progression of a poetic narrative texts to the effect that any narrative event told in the poetic narration of poetic narrative texts has been placed or located at a narrative level of the narrative clue where the narrative action that ought to be placed in the narrative progression of the poetic narration in poetic narrative texts in the process of the textual production of poetic narrative texts with regard to the specific temporal configuration or distribution of the narrative components in temporal design of the narrative events in the poetic narration of poetic narrative texts.

The third analysis of the narrative voice in the poetic narration of poetic narrative texts is closely related to the supposition that if the definition of narrative level in the poetic narration of poetic narrative texts has been taken a step further, the narrating instance of the first narrative action is extradiegetic and the narrating instance of the second narrative action diegetic in spite of the superficial simultaneousness of the two narrative actions in the 
narrative phenomenon of the poetic narration of the poetic narrative texts.

However, not every extradiegetic narration exists in the poetic narration of every poetic narrative text. Similarly, not every intradiegetic narration in the same narration of that poetic narrative text is bound to produce an oral narration. There are several main types of relationships between the metadiegetic narration and the first narration in the poetic narration of poetic narrative texts.

The first type of relationships in this respect is that the direct causal relationship between the events of the metadiegesis and those of the diegesis in the narrative action of poetic narrative texts makes sense, for it has given the second narration an explanatory function.

The second type of relationships in this respect is the pure thematic relationship that is absent either of the spatial and temporal continuity between metadiegesis and diegesis exists in the poetic narration of that poetic narrative text, or the relationship between contrast and analogy.

The third type of relationships in this respect is the explicitness relationship between the two story levels in the story stratification of the poetic stories in the poetic narration of poetic narrative texts grounded on the narrative fact or in another way narrative phenomenon that the poetic narration of a given poetic narrative text is likely to present first-person verbs in the configuration of the narrative performative verbs in the poetic narration of poetic narrative texts in the following two situations. The first situation in this regard is that narrator calls himself as narrator and the second is that the narrator is the one of the characters in the story (Gerald Genette, trans. by Rong-wen Wang, 212-259) told in the poetic narration of poetic narrative texts.

To be short, it can be generally concluded that the reasonability the specific justification of the theoretical construction of the narrative discourse in the poetic narration of poetic narrative texts has turned out to be evident in the five analyses that have been made of above grounded on the succinct justification of the feasibility of the narrative order, narrative duration, narrative frequency, narrative mood as well as narrative voice that have been regarded as the indispensable components of the narrative discourse in poetic narrative texts owing to the important roles they have been playing in the specific discursive construction, the special discursive formation as much as the irreplaceable discursive configuration of the poetic narration in poetic narrative texts except for the justification of discursive modes in the poetic narration of poetic narrative texts owing to its relevance to the poetic narration in poetic narrative texts.
4.4 The Structuralist Construction of the Nonnarrative Discourse in Poetic Narration in Poetic Narrative Texts

Just as what has been manifested in the discursive analysis of the non-narrative discourse in the novelist narration of novelist narrative texts, the structuralist analyses of non-narrative discourse in novelist narrative texts refer to the narrator's understanding of or comments on novelist story in the light of the narrative events, narrative environments and narrative characters in the novelist narrative texts in accordance with the theoretical insights of structuralist narratology.

Different as it might be from the discursive analyses of the narrative discourse in the narration of novelist and poetic narrative texts respectively, some of the theoretical insights in this respect can be absorbed selectively according to the specific discursive configuration of poetic narrative texts as required.

In careless contrast with the theoretical construction of the narrative discourse in the poetic narration of poetic narrative texts from the perspective of structuralism, it seems to be absurd to make an analysis of the theoretical construction of the non-narrative discourse in the poetic narration of poetic narrative texts but actually it is not the case, for the concentration of non-narrative discourse is based on the values, conceptions as well as voices of the poetic narrators in poetic narrative texts either in an explicit way or in an implicit way in the process of the articulation or permeation of their views into the narrative discourse and character discourse in poetic narrative texts. Considering the substantial possibility of this narrative misconception in the discursive studies of the poetic narration of poetic narrative texts, before the theoretical justification of the non-narrative discourse in the poetic narration of poetic narrative texts, it is quite necessary to place an emphasis on the argument that there is no nonnarrative discourse in the poetic narration of poetic narrative texts by claiming that all the discursive narrations in poetic narrative texts are narrative discourse without knowing that narrative discourse and nonnarrative discourse have been existing in the narration of the same narrative texts that are not reduced to poetic narrative texts. It is incorrect for poetic scholars to separate narrative discourse from non-narrative discourse, to mix narrative discourse with non-narrative discourse or to identify the narrative discourse with the non-narrative discourse in the discursive analyses of the poetic narration in poetic narrative texts.

Based on the emphasis placed above, it has been made possible to make an exploration of the actual possibility of whether the non-narrative discourse exists in poetic narrative texts or not one after another in the following three respects including the covert comments, overt comments and ambiguous comments that have been made 
either directly or indirectly by the poetic narrators of poetic narrative texts.

The first exploration of the non-narrative discourse in the poetic narration of poetic narrative texts is inclined to focus on the covert comments of the narrator in poetic narration in combination with the specific articulation of the poetic narrator in poetic narrative texts by means of interpreting possible phenomenon in the poetic stories of poetic narrative texts, analyzing everything related to narrative events, narrative characters as well as narrative actions, and revising the incorrect values, views as much as voices articulated in the poetic narrative texts.

The second exploration of the non-narrative discourse in the poetic narration of poetic narrative texts is typified in the overt comments of the poetic narrator in the poetic narration of poetic narrative texts. Generally, the overt comments are characterized with the impression left on poetic readers that the poetic narrator in poetic narrative texts has keeping them from his true identity while giving his opinions on everything he wants to by means of making his comments on everything either in a dramatic way or in a rhetorical way in line with the discursive structure and discursive techniques of the poetic stories in poetic narrative texts.

The third exploration of the non-narrative discourse in the poetic narration of poetic narrative texts has been exemplified in the ambiguity of a series of comments on everything in the narrative progression of the poetic stories in poetic narrative texts as what has been made by the poetic narrators between their covert comments and overt comments by taking advantage of the linguistic ambiguity of the narrative language and the semantic polysemy of the narrative language in the poetic narration of poetic narrative texts by means of making insinuating comments on everything they have seen for the aims of weakening the hurt brought by the implicit way they have chosen to articulate their views and deepening their awareness of everything they have come across in the textual world of poetic narrative texts while voicing their views in order to remind other characters of the incorrect opinions they have come up with.

To sum up, the theoretical construction of the nonnarrative discourse in the poetic narration of poetic narrative texts from the perspective of structuralism has turned out to be feasible based on the relevant theoretical justifications of the covert comments, overt comments as well as ambiguous comments of the poetic narrators in the poetic narration of poetic narrative texts in addition to the practical test of the discursive validity of this nonnarrative discourse of the poetic narrators in the poetic narration of poetic narrative texts by means of making correspondent discursive analyses of those non-narrative discourses.

\section{CONCLUSION}

5.1 Major Findings

Grounded on the respective analyses and explorations that have been made of the poetic narrations, poetic stories, the narrative discourses, and the non-narrative discourses in the poetic narration of poetic narrative texts in the process of constructing the theoretical framework of poetic narratology from the perspective of structuralism, a conclusion can be drawn from those justifications that it is reasonable to lay a foundation for the theoretical construction of poetic narratology from the perspective of structuralism as supported by the follwing four major findings.

The first feasibility for the theoretical construction of the theoretical framework of poetic narratology from the perspective of structuralism can be manifested in the feasibility of the structuralist construction of the poetic narration in poetic narrative texts in terms of the narrative perspectives of poetic narration in poetic narrative texts, the narrator of poetic narration in poetic narrative texts, the narratee of poetic narration in poetic narrative texts, the narrative time of poetic narration in poetic narrative texts, the narrative space of poetic narration in poetic narrative texts, the narrative forms of poetic narration in poetic narrative texts and the narrative functions of poetic narration in poetic narrative texts.

The second feasibility for the theoretical construction of the theoretical framework of poetic narratology from the perspective of structuralism has rested much on the reasonability of the structuralist construction of the poetic story in poetic narrative texts in terms of the narrative plot of poetic narration in poetic narrative texts, the narrating characters of poetic narration in poetic narrative texts, the narrative environments of poetic narration in poetic narrative texts, the narrative grammars of poetic narration in poetic narrative texts and the narrative events of poetic narration in poetic narrative texts.

The third feasibility for the theoretical construction of the theoretical framework of poetic narratology from the perspective of structuralism counts much on the adequate theoreticality of the structuralist construction of the narrative discourse in poetic narrative texts in terms of the narrative order of poetic narration in poetic narrative texts, the narrative duration of poetic narration in poetic narrative texts, the narrative frequency of poetic narration in poetic narrative texts, the narrative mood of poetic narration in poetic narrative texts and the narrative voice of poetic narration in poetic narrative texts.

The fourth feasibility for the theoretical construction of the theoretical framework of poetic narratology from the perspective of structuralism is reflected in the appropriate systematicality of the structuralist construction of the non-narrative discourse in poetic narrative texts in terms of the covert comments of poetic narrator in poetic

Page | 83 
narrative texts, the overt comments of poetic narrator in poetic narrative texts and the ambiguous comments of poetic narrator in poetic narrative texts.

Therefore, the theoretical construction of the theoretical framework of poetic narratology from the perspective of structuralism in the poetic narration of poetic narrative texts is feasible in terms of the poetic narration, poetic story, narrative discourse and non-narrative discourse in poetic narrative texts.

\subsection{Implications}

The expectable implications of this study can be approached in the following three folds:

In the first place, this study may firstly give some academic illuminations to poetic scholars, poetic critics and poetic theorists by reminding them of thinking about the possibility, the feasibility, the way and the significance to construct poetic narratology and by absorbing the recent typical academic achievements and applying them into the specific practices in the theoretical construction of poetic narratology in order to promote the systematization, the theorization, disciplinization and popularization of poetic narratology; secondly helps them give a critical account of the poetic narrative texts from the perspective of poetic narratology and regard it as a poetic theories that can be used in their practices of poetic criticism; thirdly alert them to transfer their academic identity of poetic narratoloists from their previous academic identities of poetic scholar, poetic critics and poetic theorists due to the insightful views they propose in this field; and fourthly shed some lights on the poetic production of the narrative poets who prefer to write narrative poetry.

In the second place, this study might have some impacts on narratologists in the light of combing narrative studies with poetic studies. In order to do so, they may try to have a good understanding of poetic knowledge by enrich their poetic reading in their spare time to accumulate enough knowledge and acquire enough poetic information to enable them to link poetic studies with the narrative studies and develop their poetic literacy. In fact, this accumulation in those respects is quite necessary and good for them to offer valuable suggestions to develop and improve poetic narratology in their future studies. Apart from this, their attentions to poetic appreciation are also to the advantage of their individual amusements in an elegant way.

In the third place, what the poetic readers of poetic narrative texts can be enlightened from this study is that they might learn from their poetic reading some narrative thinking by bearing in their mind that poetic reading is closely related to narrative reading because this can help them develop both their poetic literacy and narrative literacy and broaden their horizon at the same time.

www.ijels.com

\subsection{Limitations}

Due to the limited accumulation of both poetic literacy and narrative literacy of the author of this study, some predictable limitations might exist in this study that will be elaborated as below in details:

The first limitation is that some grammar mistakes might be made in the process of writing due to the carelessness of the author, the complexity of the theories that have been taken as analytical instruments to combine poetic studies with narrative studies in order to construct poetic narratology.

The second limitation is that some international studies made by western scholars might be neglected because of the limited way to search for all academic resources that can throw some lights on or give some valuable illuminations to this study. Although great efforts have been made to improve this situation, it is still inevitable to make this unintentional mistake.

The third limitation is that the understanding of poetic studies and narrative studies might seem to be superficial in the process of writing this essay due to the limited reading experience of the author of this study.

The fourth limitation is that the essay appears not to be profound enough and concrete enough to finish the entire justification of the academic proposition of the theoretical construction of poetic narratology. Since this is just a beginning of for the theoretical explorations in this respect, the textual space of this essay is limited for the complete argumentation of the academic proposition by means of citing textual examples to clarity each points, which will be done in the dissertation.

The fifth limitation is that the transition of this study from one sentence to another and from one paragraph to another might not be natural enough in a logical way due to the carelessness of the author of this essay but the fact that the composition of an essay is a logical construction has been deeply rooted in his mind. The author of this essay is not on purpose to have made those mistakes. Friendly forgiveness and suggestions will be expected from friendly scholars and experts here and there.

The sixth limitation is that some seemingly aggressive remarks might exist in this essay but it is not purposeful for the author to do so. If it does harm to any scholars, their generous tolerance will be expected.

\subsection{Suggestions}

Based on the six possible limitations of this essay as mentioned above, six predictable suggestions for the part of the author of this essay will be given as below:

The first suggestion is to be more careful to avoid making some unintentional grammar mistakes owing to the carelessness of the author of this essay in the process of writing new essays in the future studies. 
The second suggestion is to search for and read more extensive monographs and critical essays in this field to find out all academic enlightenments resources that can throw some lights on or give some valuable illuminations to this study.

The third suggestion is to have a better understanding of poetic studies and narrative studies in an overall way to highlight the profundity of the studies in this respect and avoid the superficiality of them in the process of writing new essays in the future.

The fourth suggestion is to give more conclusive evidence to show the profundity and persuasiveness of the further justification of the academic proposition of this essay in future studies.

The fifth suggestion is to make appropriate use of some transitional words to make the transitional expressions from one sentence to another and from one paragraph to another more natural in future studies.

The sixth suggestion is to avoid using aggressive remarks to do harm to others in future studies for the aim of having harmonious communications with one another.

\section{REFERENCES}

[1] Bal, Miek. (1997). Narratology, Toronto: University of Toronto Press, p: 112-113.

[2] Brian McHale. (2009). Beginning to Think about Narrative in Poetry, Narrative, p: 12-19.

[3] Bi-wu Shang. 2009. The New Developments of Narrative Studies: An Interview of David Herman, Foreign Literature, 5, p: 98-105.

[4] . ---.2012. Trans-generic Narrative Studies and the Construction of Poetic Narratology, 5, p: 14

[5] Cohn, Dorrit, Transparent Minds. (1978). Narrative Modes for Presenting Consciousness in Fiction, Princeton: Princeton University Press.

[6] Culler, Jonathan. (1981). Story and Discourse in the Analysis of Narrative in the Pursuit of Signs, Ithaca: Cornell University Press.

[7] DeJong, Iren J.F. (1987). Narrators and Focalizers: The Presentation of the Story in the Iliad, Amsterdam: B.R. Grüner, p: 1-5.

[8] Fludernik, Monika. (2005). Allegory, Metaphor, Sense and Expression: The Examples of English Medieval and Early Modern Lyric Poetry, in Theory into Poetry: New Approaches to the Lyric, ed. by Eva Müller-Zettelmann and Margarete Rubik, New York: Rodopi, p: 99-124.

[9] Fei Jiang. (2006). The Intensity of Narrative and Modern Chinese Poetry Based on Poetic Samples and the Original Design of Poetic Narratology, Journal of Qinzhou Teachers' College, 4, p: 5-8.

[10] Genette, Gerard. (1988). Narrative Discourse Revisited, trans. by Jane E. Lewin, Ithaca: Cornell University Press.
[11]---.(1980). Narrative Discourse: An Essay in Method, trans. by Lewin, Jane E., New York: Cornell University Press 33-212.

[12]---. (1990). Narrative Discourse, trans. by Rong-wen Wang, New York: Cornell University Press, p: 3145.

[13] Hogan, Patrick Colm. (2003). Extending the Theory: Emotional Prototypes, Narrative Junctures and Lyrical Poetry, in The Mind and Its Stories: Narrative Universals and Human Emotions, Cambridge: Cambridge University Press, p: 152171.

[14]Hühn, Peter. (2005). Plotting the Lyric: Forms of Narration in Poetry, in Theory into Poetry: New Approaches to the Lyric, edited by Eva MüllerZettelmann and Margarete Rubik, New York: Rodopi, p: 147-172.

[15] ---: Trans-generic Narratology. (2005). Application to Lyric Poetry, in The Dynamics of Narrative Form: Studies in Anglo-American Narratology, edited by, John Pier, Berlin and New York:de Gruyter, p:139-158.

[16]Hühn, Peter and Jens Kiefer (trans. by Alastair Mathews). (2005). The Narratological Analysis of Lyric Poetry: Studies in English Poetry from the 16th to the $20^{\text {th }}$ Century, Berlin and New York: de Gruyter, p: 1-233.

[17] Jun Luo. (2012). Towards the New Realm of Western Narrative Theories: Poetic Narratology, Journal of Changchun University of Science and Technology, 7 (4), p: 81-82.

[18]---.(2012). Towards the New Realm of the Studies of Poetic Narratology: Constructing the Narrative Grammar of Poetry. Journal of Changchun University of Technology (Social Science Edition), 24(2) p: 103-105.

[19]----.(2012). A Cognitive Study of Poetic Narratology. Journal of Yangtze University (Social Science), 35(8), p: 13-14.

[20]---. (2014). Exploration and Expectation: A Review of the Studies in Poetic Narratology, Journal of Changchun University of Technology (Social Science Edition), 26 (3) p: 98-100.

[21]----. (2012). On the Structuralist Interpretation of the Semantic Implication of Poetry Given by Their Semantic Signs, Journal of Social Sciences of Harbin Normal University, 13 (6), p: 99-101.

[22]----.(2013). Argument against Narrative Imperialism: A Multidisciplinary Approach to Poetic Narratology, Journal of Philology, 4, p: 79-81. [23]----.(2013). From Uncertainty to Certainty. Literary Education, 8, p: 11-12.

[24]----.(2013). An Exploration of the Fragmented Narrative Modes of Poetic Narratology Based on the 
Fragmented Narration of Modern Poetic Narrative

Texts. Journal of Changchun University of Technology (Social Science Edition), 25 (1), p: 110112.

[25] Jun Luo, Zhi-min Yang. 2013. An Exploration of the Desemanticized Narrative Mode of Poetic Narratology from the Lexical Transformation of the Narrative Performative Words of the Poetic Texts of Narration. Youth Literati, 475, p: 46-47.

[26] Jun Luo, Qing Yin. 2015(1). On the Theoretical Construction of the Structural System of the Semiotic Atoms in the Semantic Signs of Poetic Narrative Texts. Asian Journal of Social Science Studies, 1(1)p: 39-47.

[27] Jun Luo, Qin Liu. 2016. Towards the Narrative Intertextuality in Poetic Narratology: An Intertextual Analysis of Lawrencian Birds, Beasts and Flowers. World Journal of Social Science Research, 1(1) p: $22-43$.

[28] Jun-qiang Tan. 2013. On the Narrative Studies of Lyrical Poetry: Poetic Narratology, Thinking, p: 119-124.

[29] Li Zang. 2002. Poetic Narratology in Memories: A Close Reading of A Watch Maker's Memories. Poetic Exploration (Vol.1-2), p: 54-73.

[30] Kinnery, Claire Regan. (1992). Strategies of Poetic Narrative: Chaucer, Spenser, Milton, Eliot, Cambridge: Cambridge University Press, 1992, p: 110.

[31] Rimmon-Kenan, Shlomith. (1983). Narrative Fiction: Contemporary Poetics, London: Methuen.

[32] Sommer, Roy. (2005). Drama and Narrative, Routledge Encyclopedia of Narrative Theory, edited by Herman, David, et al., London and New York: Routledge, p: 120.

[33] Ya-min Hu.(2014).Narratolohy. Wuhan: Huazhong Normal University Press, p: 18-85, p: 141-185. 